Dharmaveer Singh ${ }^{1}$, Rajan D. Gupta ${ }^{1}{ }^{2 *}$, Sanjay K. Jain ${ }^{3}$

${ }^{1}$ GIS Cell, Motilal Nehru National Institute of Technology Allahabad - 211004, (India); e-mail:veermnnnit@gmail.com

2 Department of Civil Engineering, Motilal Nehru National Institute of Technology, Allahabad - 211004, Uttar Pradesh (India); Tel: +91-532-2271308 (O); +91-5322541505/2271708 (R), Fax: +91-532-2545341, e-mail: gupta.rdg@gmail.com, * Corresponding author

3 Water Resources Systems Division, National Institute of Hydrology, Roorkee 247667 (India); e-mail: sanjay.nih@nih.ernet.in

\title{
STUDY OF LONG-TERM TREND IN RIVER DISCHARGE OF SUTLEJ RIVER (N-W HIMALAYAN REGION)
}

ABSTRACT. Sutlej basin, a mountainous river basin is located in N-W Himalayan region. This basin has highest potential for hydropower generation as compared to other basins of Indus River system. Recent studies have revealed rise in mean annual surface temperature which will modify pattern of Sutlej River flow in this basin. The present paper has aimed for studying annual and seasonal patterns of river discharge at different gauging sites of Sutlej River basin (middle catchment), India. The study has been performed over three gauging sites, namely, Kasol, Sunni and Rampur located under different physiographic and climatic conditions. The daily historical records (1970-2010) of 41 years river discharge data have been employed for statistical analysis. The annual and seasonal Standardized Discharge Indices (SDI) has been derived in order to preserve uniformity and facilitate comparison between flows of Sutlej River at different sites. Mann-Kendall (MK) test, a non-parametric test method, has been applied to detect trend in annual and seasonal SDI for periods 1970-2010. Decadal (annual and seasonal) patterns in SDI have also been discussed. The results of annual and seasonal trend analysis have revealed decreasing trends in SDI at all the gauging sites. The trend in annual SDI is statistically significant (95\% confidence level) at Rampur (0,04 cumec/year) and insignificant at Kasol (0,02 cumec/year) and Sunni
(0,01 cumec/year) respectively. The study of annual decadal change in SDI at all the sites shows that reduction in river discharge has occurred in the decade of 2001-2010. Before this, continuous rise in annual discharge has been reported at all the sites from decades 1970-1980 to the last decade of $20^{\text {th }}$ century (1991-2000). The decline in river flow may affect agriculture and electricity production as well as there may be problems related with drinking water. The present study is expected to be useful for planning water resources related projects that can be undertaken in the Sutlej basin.

KEY WORDS: Standardized Discharge Indices (SDI), Mann-Kendall test, discharge, trend analysis, N-W Himalaya

\section{INTRODUCTION}

Anthropogenic activities (e.g. burning of fossil fuels, deforestation and land use practices) have increased concentration of Green House Gases (GHGs) in the Earth's atmosphere [IPCC, 2007]. GHGs absorb solar radiation reflected by the Earth surface and have attributed to global warming [Loaiciga et al., 1996; Srinivas et al., 2013]. Some authors have claimed that increase in temperature may enhance rates of evapotranspiration and precipitation, which will in turn may intensify hydrological cycle and affect water 
resources systems [Arnell, 1999; Xu et al., 2011]. These impacts will vary spatially as well as temporally for different regions of the earth. This has been affirmed by recent regional studies undertaken across the globe [Parry et al., 2007]. Generally, results derived from these studies have indicated negative impacts of climate change on water resources (in long-term) however some regions may be benefited.

$\infty$

Effect of climate change on discharges and snow cover in Finland has been studied by Vehvilâinen and Lohvansuu [1991] under hypothetical scenario (doubling $\mathrm{CO}_{2}$ concentration). Their study has predicted increase in mean discharge by $20-50 \%$ and vanishing of winter snow cover in Southern Finland. Whitfield and Cannon [2000] examined climatic and hydrologic variations over Canada for the decades of 1976-1985 and 1986-95 and revealed mixed patterns of change in river discharge. Mimikou and Fotopoulos [2005] have inspected impacts of climate change on the water cycle of the Aliakmon river basin in Western Macedonia and predicted reduction in mean monthly runoff for future period. A similar pattern of change in stream flow has also been observed in upper watershed of the snowmelt driven Limari river basin in NorthCentral Chile [Vicuna et al., 2011]. In this line of study, impacts of climate change on headstream runoff in the Tarim river basin have been scrutinized by $\mathrm{Xu}$ et al. [2011]. Their results have revealed rise in temperature which has caused melting of glaciers and resulted increase in runoff. However, glacier melt water would be exhausted due to continual glacier shrinkage and increased trend of runoff in the headstream may also slow or lessen. These could result in increased water stress on both agricultural and natural ecosystems [Gao and Giorgi, 2008].

From the study of Vicuna and Dracup [2007], it has been concluded that snow and glacier-fed rivers of the world are more inclined to changes in temperature because it determines snow accumulation and snow melt processes i.e. timing of snow melt runoff. Indus, Ganga and Brahmaputra rivers which originate from the glaciers of the Himalaya have great potential to suffer from the effects of global warming [IPCC, 2007]. Such concerns have been supported by reports of significant retreat and depletion of glacier volume across the Himalayan region [Singh and Kumar, 1997; Naithani et al., 2001; Shrestha et al., 2004; Berthier, 2007; Eriksson, 2009]. The temperature driven snow and glacier-melt would have profound impacts on annual and seasonal runoff of the rivers. Initially, increase in runoff will occur with increase in temperature but for prolonged period of warming, runoff will fall sharply due to shrinkage in glacial mass [Rees and Collins, 2005]. It is predicted that at this present rate of retreat, glaciers in the region will vanish within 40 years [WWF Nepal Program, 2005]. This will lead to significant decline in discharge of major river systems flowing through this region and widespread water shortages.

Thus, the study of long-term trends in stream runoff is highly required for understanding implications of climate change on water resources in the Himalayan river basins. However, lack in monitoring stations, poor data availability in addition to physical inaccessibility has limited number of studies in the region. Recently, Bhutiyani et al. [2008] examined trends in annual and seasonal discharge of four rivers in NorthWest Himalaya (NWH). Their results have indicated insignificant increase in annual and monsoonal discharge of Chenab river during 1969-1998 and Ravi river during 19651992. Opposite to this, significant decrease in annual and monsoonal discharge has been reported for Beas river during 19611995 followed by insignificant decrease in discharge of Sutlej River during 1961-2004 respectively. However, for Sutlej River, the trend in annual and seasonal discharge has been measured at Bhakara downstream of the Sutlej River.

Sutlej basin, formed by Sutlej River is blessed with huge hydropower generation 
potential due to its unique topographical setting and availability of abundant water. Hence, several hydropower projects have been installed on this river. The variability in patterns of river discharge triggered by global climate change may affect production of electricity and agricultural practices in the basin. Keeping the above in mind, the main objective of this paper is to study annual and seasonal patterns of discharge in Sutlej River at different gauging sites (upstream from Bhakara) in NWH region, India.

\section{MATERIALS \& METHODS}

\section{Study Area}

The present study has been carried out in a part of Sutlej River basin that is confined in the hilly State of Himachal Pradesh, India. The State shares its boundary with four Indian States namely, Jammu and Kashmir from North, Punjab from West, Haryana from South, Uttarakhand from South-East and has international border with China (Tibet). It covers parts of Simala, Kullu, Mandi, Bilaspur and Solan districts of Himachal Pradesh. This has a spread of $2457 \mathrm{~km}^{2}$ and lies between $31^{\circ} 05^{\prime} 00^{\prime \prime} \mathrm{N}$ and $31^{\circ} 39^{\prime \prime} 26^{\prime \prime} \mathrm{N}$

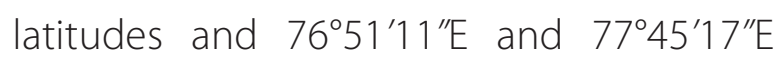
longitudes (Figure 1). Sutlej River basin is drained by the Sutlej River which originates from Mansarovar- Rakastal lakes near Darma pass in the western Tibet at an elevation of $4,570 \mathrm{~m}$. The basin is characterized by steep slope, dissected topography and high relief features. The mean annual temperature and precipitation has been recorded $21,23^{\circ} \mathrm{C}$ and $103 \mathrm{~cm}$ respectively. The identified hydropower potential in this basin is 9226,75MW (megawatt). The major hydropower projects installed on the Sutlej River within the study area are Sunni Dam Project of $1080 \mathrm{MW}$, Rampur Hydro-electric Power Project (RHEP) of 412MW and Nathpa Jhakari Hydro-electric Power Project (NJHEP) of $1500 \mathrm{MW}$.

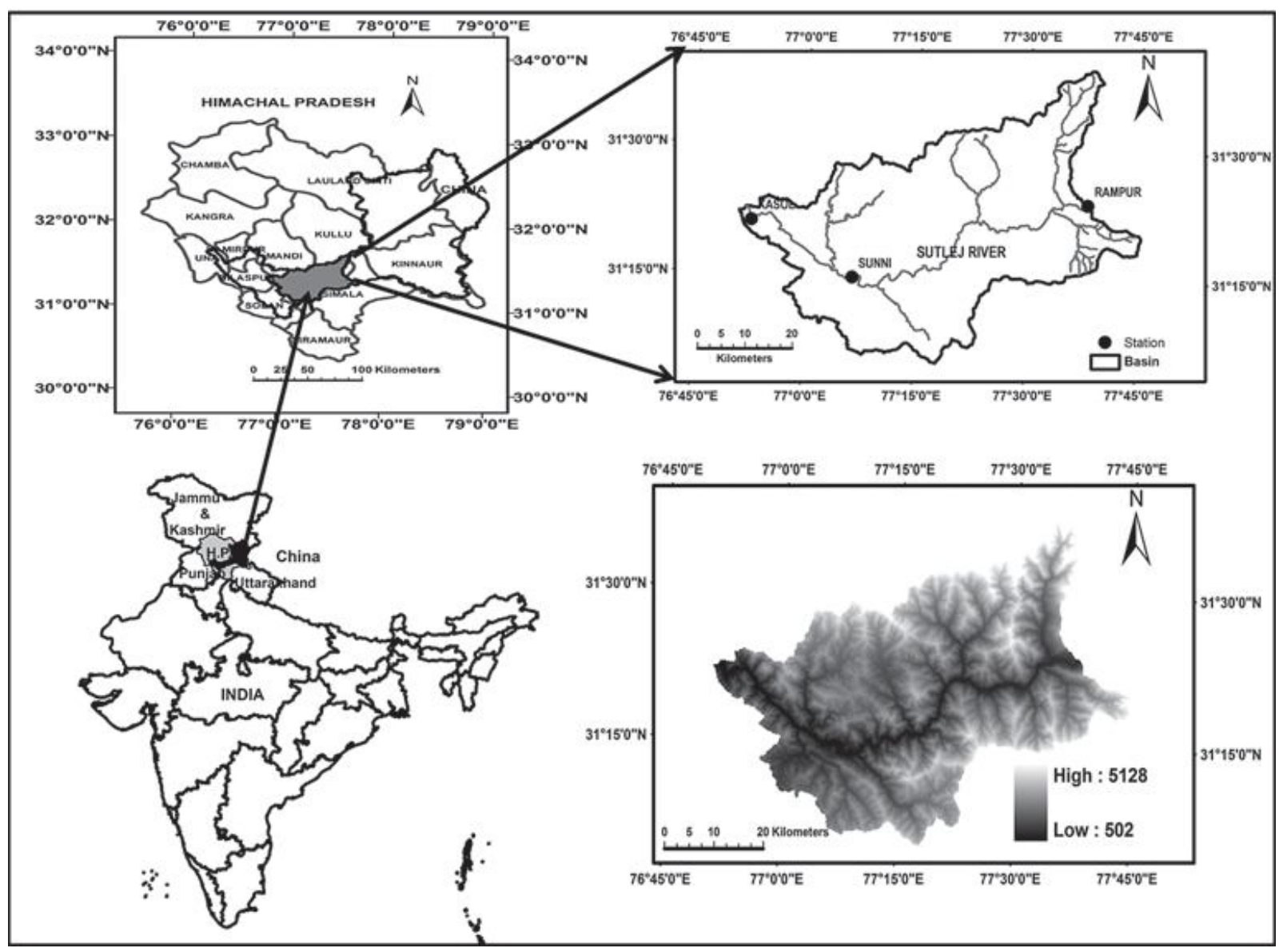

Fig. 1. Location map of the study region. 
Table 1. Location details of the stations considered for the study in Sutlej basin

\begin{tabular}{|l|c|c|c|c|c|}
\hline \multicolumn{1}{|c|}{ Station } & Latitude & Longitude & Elevation $(\mathbf{m})$ & $\begin{array}{c}\text { Mean Annual } \\
\text { Discharge } \\
\text { (cumec) }\end{array}$ & $\begin{array}{c}\text { Standard } \\
\text { Deviation } \\
\text { (cumec) }\end{array}$ \\
\hline Kasol (1970-2005) & $31^{\circ} 21^{\prime \prime 2} 5^{\prime \prime}$ & $76^{\circ} 52^{\prime} 42^{\prime \prime}$ & 662 & 12636.6 & 1976.9 \\
\hline Sunni (1970-2005) & $31^{\circ} 14^{\prime \prime} 15^{\prime \prime}$ & $77^{\circ} 06^{\prime} 30^{\prime \prime}$ & 655 & 1177.5 & 1933.6 \\
\hline Rampur (1970-2005) & $31^{\circ} 27^{\prime \prime} 15^{\prime \prime}$ & $77^{\circ} 38^{\prime} 40^{\prime \prime}$ & 976 & 10331.7 & 1903.4 \\
\hline
\end{tabular}

\section{Data Availability and Sources}

The long-term discharge data used in the present study has been collected and supplied by Bhakra Beas Management Board (BBMB) for three gauging sites; Kasol, Sunni and Rampur. These data are available from 1970 to 2010 for the period of 41 years on daily time step. The locations of given stations have been shown in Fig. 1 earlier while the details of the data have been described in Table 1. For the analysis, daily values of discharge are summed to obtain annual and seasonal values at each site.

\section{Methodology}

Standardized Discharge Indices (SDI). The concept of Standardized Discharge Indices (SDI) has been adopted from the study of Bhutiyani et al. [2008]. This has been used to bring uniformity and facilitate comparison between the hydrological responses (flows) of Sutlej River at different gauging sites. The monthly (for seasonal analysis) and yearly (for annual analysis) discharge data has been standardized by subtracting their mean and dividing by their standard deviation averaged over period 1970-2010 from the time series as shown in equation 1.

$$
X_{S D I}\left(\frac{X_{i}-X_{\text {mean }}}{S D}\right) \text {, }
$$

Where, $X_{i}$ is observed time series of discharge, $X_{\text {mean }}$ is mean discharge averaged over period 1970-2010 and SD is standard deviation of discharge during this period. In this way, annual and seasonal SDI for each site has been computed.

\section{Mann-Kendall (MK) Trend Analysis}

Method. MK test is a non-parametric rank based test and has been used widely for analyzing trend in hydrologic and climatologic variables [Mann, 1945]. It has advantage over other tests as it is distribution-free and robust against outliers [Hess et al., 2001]. It assumes that the time series under research are stable, independent and random with equal probability distribution [Zhang et al., 2005].

In MK test, null hypothesis $\left(H_{0}\right)$ of no trend is checked with the alternative hypothesis $\left(H_{j}\right)$ of increasing or decreasing trend. The $\mathrm{S}$ statistics of MK test is defined as [Jain and Kumar, 2012]:

$$
S=\sum_{i=1}^{n-1} \sum_{j=i+1}^{n} \operatorname{sgn}\left(x_{j}-x_{i}\right)
$$

where $\mathrm{n}$ is the number of data points, $x_{j}$ is observed value at time $j$ and $x_{i}$ is observed value at time $i$. The value of $\operatorname{sgn}\left(x_{j}-x_{i}\right)$ is computed as shown in equation 3 :

$$
\operatorname{sgn}\left(x_{j}-x_{i}\right)= \begin{cases}+1, & \left(x_{j}-x_{i}\right)>0 \\ 0, & \left(x_{j}-x_{i}\right)=0 \\ -1, & \left(x_{j}-x_{i}\right)<0 .\end{cases}
$$

For samples $(n \geqslant 10)$, MK test is conducted using a normal distribution and variance of $S$ statistic is defined by:

$$
\begin{aligned}
& \operatorname{Var}(S)= \\
& =\frac{m(n-1)(2 n+5)-\sum_{i=1}^{n} t_{i}(i)(i-1)(2 i+5)}{18}
\end{aligned}
$$

in which $t_{i}$ denote the number of ties to extent $i$. 
The test statistic $Z$ is estimated as:

$$
Z=\left\{\begin{array}{cc}
\frac{S-1}{\sqrt{\operatorname{Var}(S)},} & S>0 \\
0, & S=0 \\
\frac{S+1}{\sqrt{\operatorname{Var}(S)},} & S<0 .
\end{array}\right.
$$

Ho is rejected at $\alpha$ level of significance in a two-sided test if the value of $|Z|$ is greater than $Z_{\alpha / 2}[\mathrm{Xu}$ et al., 2008]. The statistical interpretation of the rejection of Ho at given $\alpha$ level of significance implies a probability $\alpha$ that a trend is falsely identified. The significance level is taken as a criterion in hypothesis testing for rejection of Ho. The level of significance is a subjective issue and has been found between 1\% to 10\% level (mostly 5\% level) in several research studies [Patra et al., 2012]. In this study, Ho is tested at 5\% level of significance $(Z 0.025=1.96)$.

Sen's slope method is used to compute magnitude of trend line. This is defined as the median of all combination of data pairs for the whole data set. It is given as follows [Xu et al., 2008]:

$$
Q=\operatorname{Median}\left(\frac{x_{j}-x_{i}}{j-i}\right) \text { for } i=1,2, \ldots, n,
$$

where $x_{i}$ and $x_{j}$ are data values at time $i$ and $j$ respectively.

$Q$ is an estimate of the trend magnitude. Positive value of $Q$ indicates an upward (increasing) trend and negative value of $Q$ indicates a downward (decreasing) trend in time series.

\section{RESULTS}

\section{Site Wise Trends in Annual and Seasonal SDI Using MK Test for 1970-2010}

The annual pattern of trend in SDI for period of 1970-2010 has been shown in Fig. 2. The decreasing trend in SDI has been reported at Kasol followed by Sunni and Rampur. The trend is statistically insignificant at 95\% level of confidence at Kasol and Sunni but it is statistically significant at Rampur. The rate of decrease is 0,02 cumec/year (Kasol), 0,01 cumec/year (Sunni) and 0,04 cumec/year (Rampur) respectively. In this way, highest decrease in annual discharge has been found at Rampur and minimum at Sunni.

Table 2 provides the summary of seasonal trend analysis of SDI for 1970-2010.

Generally, decreasing trends in SDI have been found at all sites. The trends are statistically significant at Sunni and Rampur during summer (June, July and August) and autumn (September, October and November) seasons. The rate of change is 0,32 cumec/year, 0,031 cumec/year at Sunni and 0,47 cumec/year, 0,034 cumec/year at Rampur respectively. The winter (December, January and February) and spring (March, April and May) seasons are characterized by statistically insignificant decreasing trends in SDI at all the sites. The rate of decrease is highest during summer season.

\section{Decadal Change in Annual and Seasonal SDI for 1970-2010}

Decadal (annual and season wise) change in SDI has been computed for the period of 1970-2010 to determine whether the rate

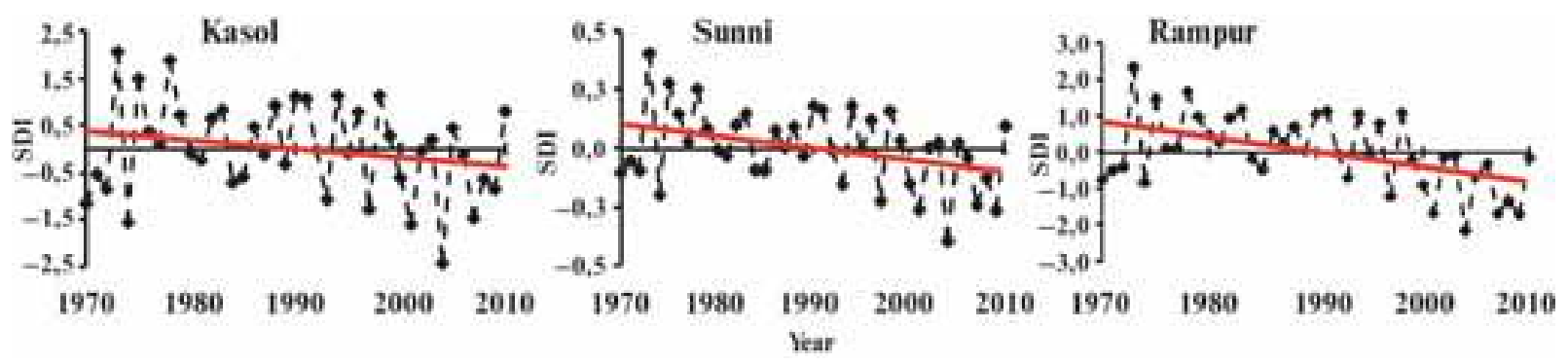

Fig. 2. Annual trends in SDI at Kasol, Sunni and Rampur for 1970-2010. 
Table 2. Seasonal trend analysis of SDI for 1970-2010 performed at all sites

\begin{tabular}{|c|c|c|c|c|}
\hline Station & Season & $Z_{s}$ & $\mathrm{Q}\left({ }^{\circ} \mathrm{C} /\right.$ year $)$ & Remarks \\
\hline \multirow{4}{*}{ Kasol } & Winter & $(-)$ & $-0,002$ & Decreasing \\
\hline & Spring & $(-)$ & $-0,007$ & Decreasing \\
\hline & Summer & $(-)$ & $-0,021$ & Decreasing \\
\hline & Autumn & $(-)$ & $-0,013$ & Decreasing \\
\hline \multirow{4}{*}{ Sunni } & Winter & $(-)$ & $-0,008$ & Decreasing \\
\hline & Spring & $(-)$ & $-0,012$ & Decreasing \\
\hline & Summer & $(-)^{*}$ & $-0,032$ & Decreasing \\
\hline & Autumn & $(-)^{*}$ & $-0,031$ & Decreasing \\
\hline \multirow{4}{*}{ Rampur } & Winter & $(-)$ & $-0,015$ & Decreasing \\
\hline & Spring & $(-)$ & $-0,015$ & Decreasing \\
\hline & Summer & $(-)^{*}$ & $-0,047$ & Decreasing \\
\hline & Autumn & $(-)^{*}$ & $-0,034$ & Decreasing \\
\hline
\end{tabular}

(* indicates that values are statistically significant at 5\% level of significance).

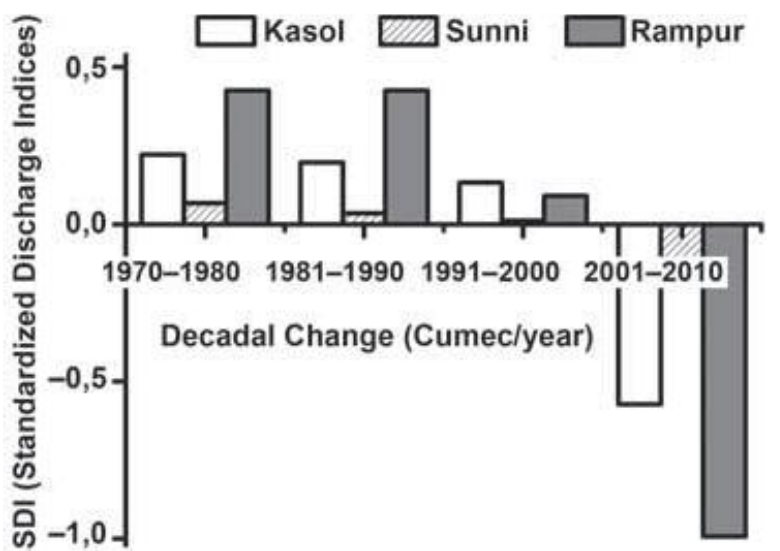

Fig. 3. Annual decadal change in SDI (cumec/year) at Kasol, Sunni and Rampur for 1970-2010.

of change at a particular station is uniform or not. The results of annual decadal change in SDI for all the sites have been shown in Fig. 3. There is a continuous reduction in river discharge in long-term. The rise in annual discharge with varying rates has been observed in decades of 1970-1980, 19811990 and 1991-2000 followed by an abrupt fall in 2001-2010 for Kasol, Sunni and Rampur sites respectively. The maximum rise and fall in river discharge has been reported at Rampur site. The recent (2001-2010) reduction in river discharge is solely responsible for having decreased annual trends in SDI observed at different gauging sites of Sutlej River.
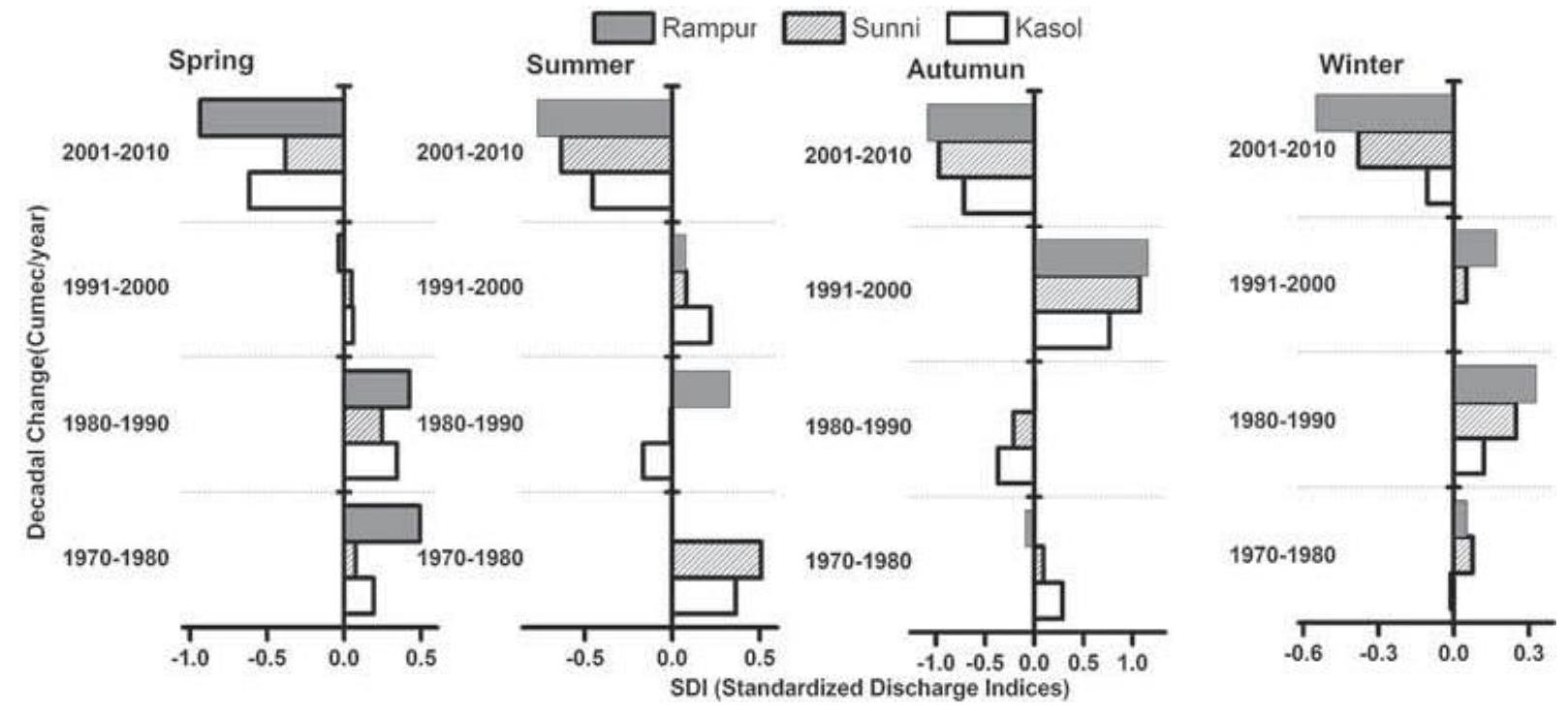

Fig. 4. Inter-decadal (seasonal) change in SDI (cumec/year) at Kasol, Sunni and Rampur for 1970-2010. 
Fig. 4 shows results of inter-decadal change in SDI at Kasol, Sunni and Rampur sites respectively. A substantial fall in SDI has been observed at each site throughout all seasons during the decade of 2001-2010. The decrease in SDI informs about reduction in flow of river water. However, more or less rise in SDI has been noticed during spring and winter seasons from 1970-1980 to 1991-2000. The nature of change in patterns of SDI is not uniform during summer and autumn seasons.

\section{DISCUSSIONS AND CONCLUSIONS}

The analysis of MK test reveals decreasing annual and seasonal trends in SDI at different gauging sites of Sutlej River for the period of 1970-2010. The annual trends are statistically significant at Rampur and insignificant at Kasol and Sunni respectively. Similarly, statistically significant decreasing trends in SDI have been observed at Sunni and Rampur during summer and autumn seasons. The decreasing trends in SDI reflect the decline in river discharge.

In the present study, a continuous rise in annual discharge has been observed at all the sites from decades 1970-1980 to the last decade of $20^{\text {th }}$ century (1991-2000). However, the results of the study of annual decadal change in SDI at all the sites shows a reduction in river discharge in the decade of 2001-2010. The decline in flow of Sutlej River may be attributed to rise in surface mean temperature over $\mathrm{NWH}$. The increase in the surface mean temperature over NWH has also been confirmed in the study of Bhutiyani et al [2009].

The initial increase in the annual discharge from 1970-1980 and then from 1991-2000 may be attributed to fact that there has been an increase in the mean surface temperature during the corresponding period which resulted in the increase of discharge due to accelerated melting of glaciers. However, during the later stage, due to shrinkage in the volume of glaciers, there is a significant decrease in the discharge of river Sutlej during the period 2001-2010 even though there was an increase in mean surface temperature during this period also. The present study thus shows the pattern of alteration in the behaviour of discharge of Sutlej River basin. Therefore, it is the need of the hour to adopt of an appropriate strategy for proper monitoring and management of water resources in the Sutlej basin in respect of global climate change.

\section{REFERENCES}

1. Arnell W (1999) The effect of climate change on hydrological regimes in Europe: A continental perspective. Global Environmental Change, Vol. 9, pp. 5-23.

2. Berthier E., Arnaud Y., Kumar R., Ahmad S., Wagnon P., Chevallier P (2007) Remote sensing estimates of glacier mass balances in the Himachal Pradesh (Western Himalaya, India). Remote Sensing of Environment, Vol. 108 (3), pp. 327-338.

3. Bhutiyani M.R., Kale V.S., Pawar N.J (2008) Changing stream flow patterns in the rivers of northwestern Himalaya: Implications of global warming in the 20th century. Current Science, 95 (5), pp. 618-624.

4. Bhutiyani M.R., Kale V.S., Pawar N.J (2009) Climate change and the precipitation variations in the northwestern Himalaya: 1866-2006. International Journal of Climatology, doi: 10.1002/joc.1920.

5. Eriksson M., Xu J., Shrestha A.B., Vaidya R.A., Nepal S., Sandstr"om K (2009) The changing Himalayas: Impact of climate change on water resources and livelihoods in the greater Himalayas, Kathmandu, ICIMOD.

6. Gao X., Giorgi F (2008) Increased aridity in the Mediterranean region under greenhouse gas forcing estimated from high resolution simulations with a regional climate model. Global Planet. Change, Vol. 62, pp. 195-209. 
7. Hess A., lyer H., Malm W (2001) Linear trend analysis: a comparison of methods. Atmospheric Environment, Vol. 35, pp. 5211-5222.

8. Intergovernmental Panel on Climate Change (IPCC), 2007. Climate change (2007). Impacts, adaptation and vulnerability. Contribution of working group II to the Fourth Assessment Report of the Intergovernmental Panel on Climate Change, edited by M. Parry et al., Cambridge University Press, UK.

9. Jain S.K., Kumar V. (2012) Trend analysis of rainfall and temperature data for India A review. Current Science, Vol. 102 (1), pp. 37-49.

10. Loaiciga H.A., Valdes J.B., Vogel R., Garvey J., Schwarz H (1996) Global warming and the hydrologic cycle. Journal of Hydrology, Vol. 174, pp. 83-127

11. Mann H.B.(1945) Nonparametric tests against trend. Econometrica, Vol. 13, pp. 245-259.

12. Mimikou M., Fotopoulos F (2005) Regional effects of climate change on hydrology and water resources in Aliakmon River basin. Regional Hydrological Impacts of Climatic ChangeImpact Assessment and Decision Making (Proceedings of symposium $\mathrm{S6}$ held during the Seventh IAHS Scientific Assembly at Foz do Iguaçu, Brazil, April 2005). IAHS Publ. 295.

13. Naithani A.K., Nainwal H.V., Sati K.K., Prasad C (2001) Geomorphological evidences of retreat of the Gangotri Glacier and its characteristics. Current Science, Vol. 80 (1), pp. 87-94.

14. Parry M., Canziani O., Palutikof J van der Linden P., Hanson C. (2007) Climate Change 2007: Impacts, Adaptation and Vulnerability, 2007, 1st edition. Cambridge University Press.

15. Patra J.P., Mishra A., Singh R., Raghuwanshi N.S. (2012) Detecting rainfall trends in twentieth century (1871-2006) over Orissa State, India. Climate Change. Vol. 111 (3-4), pp. 801-817.

16. Rees H.G., Collins D.N (2005) Regional differences in response of flow in glacier-fed Himalayan rivers to climatic warming. Hydrological Process, Vol. 20 (10), pp. 2157-2169.

17. Shrestha M.L., Wake A.B, Shrestha P.A (2004) Recent Trends and Potential Climate Change Impacts on Glacier Retreat/Glacial Lakes in Nepal and Potential Adaptation Measures, OECD Global Forum on Sustainable Development, Development and Climate Change Paris, France, OECD, pp. 5-14.

18. Singh P., Kumar N (1997) Impact assessment of climate change on the hydrological response of a snow and glacier melt runoff dominated Himalayan river. Journal of Hydrology, Vol. 193 pp. 316-350.

19. Srinivas V.V., Basu B., Kumar N., Jain S.K. (2013) Multi-site downscaling of maximum and minimum temperature using support vector machine. International Journal of Climatology doi/01002/joc.3782

20. Vehvilâinen B., Lohvansuu J (1991) The effect of climate change on discharges and snow cover in Finland. Hydrological Sciences, Vol. 36 (2), pp. 109-121.

21. Vicuna S., Dracup J.A. (2007) The evolution of climate change impact studies on hydrology and water resources in California. Climatic Change, Vol. 82, pp. 327-350.

22. Vicuna S., Garreaud R.D., McPhee J. (2011) Climate change impacts on the hydrology of a snowmelt driven basin in semiarid Chile. Climate Change, Vol. 105 pp. 469-488, doi 10.1007/s10584-010-9888-4. 
23. Whitfield P.H., Cannon A.J. (2000) Recent Variations in Climate and Hydrology in Canada. Canadian Water Resources Journal.

24. WWF Nepal Program. (2005) An overview of glaciers, glacier retreat, and subsequent impacts in Nepal, India and China; Available at http://assets.panda.org/downloads/himalayaglaciersreport2005.pdf.

25. Xu H., Zhou B., Song Y. (2011) Impacts of climate change on headstream runoff in the Tarim River Basin. Hydrology Research, pp. 20-29, doi:10.2166/nh.2010.069.

26. Xu Z., Gong T., Liu C. (2008) Decadal trends of climate in the Tibetan Plateau - regional temperature and precipitation. Hydrological Processes, Vol. 22 (16), pp. 3056-3065.

27. Zhang Q., Jiang T., Gemmer M., Becker S. (2005) Precipitation, temperature and runoff analysis from 1950 to 2002 in the Yangtze basin, China. Hydrological Processes, Vol. 50 (1), pp. 65-79.

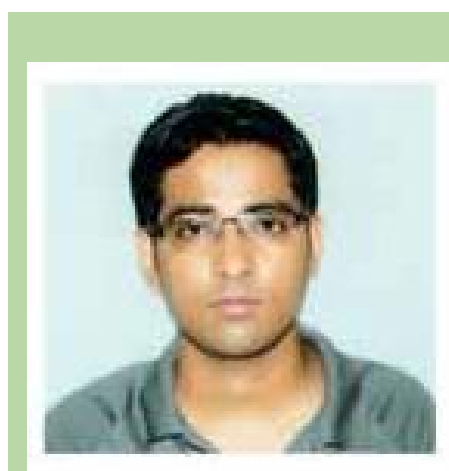

Dharmaveer Singh is currently pursuing Ph.D. in the field of Geoinformatics at the Department of GIS Cell of Motilal Nehru National Institute of Technology, Allahabad, India. He has received his B.Sc. (Hons.) degree in 2007 and M.Sc. degree in 2009 in Geography (with specialization in Remote Sensing and Cartography) from Banaras Hindu University, Varanasi, India. His research interest includes hydro-climatology, hydrological modelling, water resource management and application of GIS and remote sensing in disaster management. He is life member of Indian Association of Hydrologist (IAH). He has been awarded Junior Research Fellowship in the field of Earth Science by the Council of Scientific and Industrial Research (CSIR), India. He has published 8 papers in international/national conferences and journals.

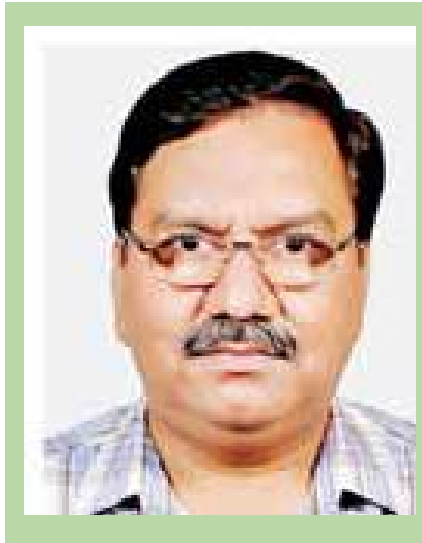

Rajan D. Gupta is Professor in Department of Civil Engineering, Motilal Nehru National Institute of Technology, Allahabad (India) having specialization in Geoinformatics. Prof. Gupta obtained his B.E. (Civil) in 1985, M.E. (Remote Sensing \& Photogrammetric Engineering) in 1990 and Ph.D. (Geoinformatics) in 2002, all from the Indian Institute of Technology (IIT) Roorkee, India. He has teaching and research experience of over 26 years and supervised Ph.D. and M. Tech thesis works in the field of Geoinformatics. He worked as Founding Coordinator for GIS Cell of the Institute and developed M. Tech. (GIS and Remote Sensing) course which was started under GIS Cell from the academic year 2006-07. He is presently working as Chief Coordinator for AICTE sponsored National Coordinated Project (NCP) on "GIS for development of Web based Public Health Information Infrastructure \& Management System". He visited several foreign countries for research paper presentation and academic interaction including Tampa (USA), Spain, Thailand, Atlanta (USA) and Suzhou (China). He has published 60 research papers in refereed journals and conference proceedings. 


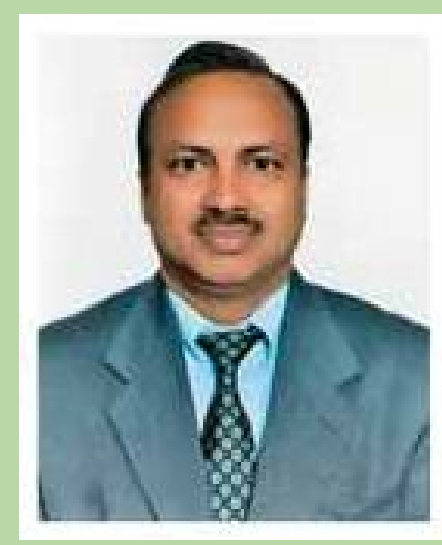

Sanjay K. Jain has received Ph.D. from Department of Earth Science, Indian Institute of Technology, Roorkee, India in 2001 and M.S. in Hydrology from the National University of Ireland, Galway, Ireland in 1997. He has more than twenty five years of experience in field of research. He is working as a scientist- $F$ in Water Resources System division at National Institute of Hydrology, Roorkee, India and Officer-in-Charge of the Indian National Committee on Climate Change (INCCC). He conducts research dealing with hydrological modelling, snow cover/ glacier mapping and snowmelt runoff modelling and impact of climate change on water resources. Dr. Jain is life member of Indian Association of Hydrologist, Indian Society of Remote Sensing, Indian Water Resources Society and International Association of Hydrological Society. He received best scientist award of National Institute of Hydrology for the year 2000. He has published 30 papers in refereed International Journals. 